\title{
Position Paper Number 2 for the Workshop "Towards Criteria of Sustainability and Social Meaningfulness in Development": Critical Reflections on Modernization Theoretical Thinking and its Implications for ICTs in Development
}

\author{
Robert M. Bichler \& Eva Gaderer
}

UTI - Unified Theory of Information Research Group, [www.uti.at], robert.bichler@uti.at ICT\&S Center, University of Salzburg, [http://www.icts.uni-salzburg.at], eva.gaderer@sbg.ac.at

I $\mathbf{n}$ this position paper we are trying to formulate a critique of the current practices in ICTs related development assistance. We are arguing that modernization theoretical approaches still serve as an ideological basis for most development activities taken out by industrialised countries. In our opinion, modernization theories are used to legitimise modern imperialism through which a global capitalistic system should be established. In the next section we will give a brief overview on modernization theory. This is followed by a description of the ways ICTs currently are tried to be implemented in the developing world. We will end with some concluding thoughts.

\section{Modernization Theoretical Thinking}

In the early 1950s development theories started to emerge as an independent academic discipline, with the aim to develop new models in order to face the east-west conflict and to oppose Soviet Unions' development theories. Menzel (1992) differs between sub-disciplines of modernizationtheories, i. e. Economy of development, theories of nation-state building, democratization-theories and the tighter modernization theories, which are based on the 'big theories' of the $19^{\text {th }}$ century. The main argument was, in opposition to Marxist theories, that intern cultural and mental factors foster underdevelopment of non- industrial societies (Menzel, 1992, p. 21). The focus on intern or engodenous factors function as the basement of the theories of modernization (Menzel, 1995, p. 21; Nuscheler, 2005, p. 214; Wehler, 1975, p. 8). They developed from Max Weber's "Die protestantische Ethik und der Geist des Kapitalismus“ (The Protestant Ethic and the Spirit of Capitalism) and the main assumption is a dualism on an economic, technological, regional, social and cultural level. Weber's sociology of religion describes the interrelation between puritan religion and economic-rational lifestyle in capitalistic ways of thinking. Not the capitalistic system itself developed from ascetic Protestantism, but the rational "ghost" or soul of capitalism, its dynamic and ascetic focus was embossed from Calvinism, in particular from AngloSaxon Puritanism (Abramowski, 1966, p. 39).

The main concept of modernization describes the development from traditional to modern societies (Wehler, 1975, p. 11). Following Nuscheler (2005, p. 214), the background of modernization theories are dualisms between tradition and modernity, between industrial centres and rural areas and between owning and non-owning classes. Due to this approach developing countries navigate in a slower pace, but in the same direction like industrial countries. In opposition to Marxist theories the goal of development is not a classless society, but a modern industrial society (Menzel, 1995, p. 21). 
Walt Whitman Rostow (1960) is an important representative of modernization theoretical approaches. His theory of stages of economical growth should offer an alternative to the Marxist development theory (Harrison, 1988, p. 26; Lachmann, 2004, p. 90; Menzel, 1995, p. 22). The foundation of Rostow's approach is the classification of societies within five steps of development, which he describes as stages of growth. For modernization theories economical growth is the basis of the modernization-process, but also a change of values within the population of a society is required (Wehler, 1975, p. 39). Economical changes have strong impacts on societies and these changes are supported by political and social transformations (Rostow, 1960, p. 17).

The process of modernization can be seen as increasing dominance of humans over their environment; this progress is inevitable and revolutionary and it emerges in certain stages (Wehler, 1975, p. 16). The first phase is the traditional society, the conditions of production are limited, science and technology are barely accessible. This society is based on agriculture and highly hierarchical structures within landowners and families (Rostow, 1960, p. 18).

The next phase can be described as a society in transformation where the preconditions for economical growth are established. The role of science and technology increases, the political system changes towards a strong nation state, which releases from traditional and regional interests and fosters investments in industrial sectors "Investments increase, especially in transport, communication and raw materials, and the result is a general commercial expansion." (Harrison, 1988, p. 26) This transformation also takes part within the population where the importance of personal property and nationalism increases (Lachmann, 2004, p. 91; Rostow, 1960, p. 47).

The next step is the economical rise, in which the industrial sector gains more and more power and starts to play a dominant role within a given society. Through the import of capital and investments the basement for new industry is laid, new employments are provided, the agricultural sector becomes commercialized, natural resources become capitalized and new methods of production develop (Rostow, 1960 , p. 22). For Rostow the precondition for the "Take-off" is an increasing quote of investments of $10 \%$, but later on, this number will be relativized by certain economic-historians, because i. e. England archived this investment quote long after the industrial revolution (Lachmann, 2004, p. 91).

A society's stadium of mature according to Rostow is accomplished when the national economy has asserted its position in the international market. He arguments that the process from traditional to mature society takes 60 years, because modern technology needs three generations for an adequate diffusion in a certain society (Rostow, 1960, p. 25). In the following stadium of mass consumption the per-capita income increases towards a level that allows more private consumption than only food and clothing, besides of that, the importance of social welfare increases (Rostow, 1960, p. 94).

The model of Rostow has often been criticized, especially by dependency theories. "In short, far from colonialism helping to modernize the Third World, it served to hinder its development." (Harrison, 1988, p. 28). Most modernization theories describe the development process of societies as an evolutionary progress. Rostow's model still is the foundation of many development theories, such as Parsons Neo-Evolutionism (Lachmann, 2004, p. 92; Harrison, 1988, p. 41).

The common ground of most modernization theories is the characterization of modern society as the 'better society', the way from tradition to modernity is the only way and should be aspired globally by all societies. Some modernization theories reflect the ethnocentric self-approval and the political and economical superiority of the US after 1945 (Wehler, 1975, p. 18). The lack of considering problems made by international politics, imperialism, colonial regimes and 
war, can also be criticized on modernization theories (Wehler, 1975, p. 55).

Due to modernization theories the main goal of development politics and development aid is the dissociation from traditional paradigm and stimulation of the industry. Apparent economical growth of traditional societies, the so-called Asian tigers are contradictory to these approaches (Nuscheler, 2005, p. 214). The most important strategies of development politics within modernization theories are economical growth and modernization, once capitalism has conquered tradition, society also benefits on a social level. According to Wehler (1975, p. 19) also Social Darwinism or racist approaches can be found within modernization theories, hidden under an intellectual imperialism that characterizes Western lifestyles as the better way to live.

To describe the level of development of a nation, modernization theories focus on internal belongings. Values within societies will have to change from traditional agricultural lifestyle towards mass consumption. The nation state has to enforce foreign investments and foster the enlargement of private property and means of production. Most of the approaches are founded in dualistic mindsets that neglect the possibility of coexistence and cooperation between tradition and modernity. Economical growth is seen as the only driving force for enhancing the living conditions of people in developing countries.

\section{A Critique of Modernization Theoretical Thinking}

In the light of modernization theoretical approaches, development is considered to be a linear, evolutionary process with a determined final goal. The current social, political, ecological, technical and foremost economical conditions of the developed world are therefore considered to be the only desirable aims of societies. Development in that sense starts at a point ' $A$ ' in time and ends at an undoubtedly defined point ' $B$ ' in the future. The whole development process is clearly structured and foreseen, derived from lessons learned in the already developed world, totally neglecting that human history is not a continuing linear progression, it is rather "made of the coexistence and interaction of different states so that the resulting movement looks more like a complex spiral" (Menou, 2008). Modernization theoretical approaches also ignore the fact that within countries different stages of development can be witnessed and that even in the developed countries various stages coexist. In global cities such as Shanghai, Rio de Janeiro, Mumbai and even New York one can easily switch between the information age in which e.g. WiFi services ${ }^{1}$ are ubiquitous and the beginning of industrialization where electricity and running water are scared resources.

A-historical arguments such as the thesis that modern capitalism and political freedom are shaping each other and hence neoliberal capitalism enhances freedom and vice versa (this was the fundamental principle of US foreign policy under George W. Bush), or that once a capitalistic system is introduced in an developing country wealth will be distributed equally, are used to support this reductionistic approach. Or, as Wallerstein summarizes such hegemonic thinking: "Development, as the term came to be used after 1945, was based on a familiar explanatory mechanism, a theory of stages. Those who used this concept were assuming that the separate units - 'national-societies' all developed in the same fundamental way (thus satisfying the nomothetic demand) but in distinct paces (thus acknowledged how different the states seemed to be at the present time). Presto! On would then be able to introduce specific concepts to study the 'others' at the present time while arguing that eventually, all states would turn out more or less the same. This sleight of hand had a practical side as well. It meant that the 'mostdeveloped' state could offer itself as a model for the 'less-developed' states, urging the latter to engage in $s$ sort of mimicry, and promising an higher standard of living and a more liberal governmental structure ('political development') at the end of the rainbow." (Wallerstein, 2004, p. 10)

WiFi also known as WLAN (Wireless Local Area Network) 
An analysis by Christian Fuchs shows that huge gaps in wealth distribution are characteristic for contemporary societies and therefore, instead of an egalitarian information society, a capitalist class system within informational capitalism is emerging (Fuchs, 2008).

Taking Saudi Arabia, a country where women are barred from driving motorised vehicles, as an example, it is getting obvious that democracy and equal rights for all in a Western sense is not necessarily connected to development.

Development takes place in countries where, following modernization theoretical ideas, development seems to be impossible. States like Saudi Arabia, which is on the basis of the GDP - per capita (PPP) the 60 richest country in the world (CIA World Fact Book, 2009), demonstrate that such approaches totally fail in predicting development. ${ }^{2}$ The country demonstrates the importance of external factors for development, e.g. the exploration of oil fields, the existence of row materials, which might become important in future technological innovations and also natural disasters such as earthquakes, hurricanes etc., which are neglected in modernization theories. The same applies for internal factors. Modernization theories fall short in describing for example spontaneous selforganised civil unrests, like the ones e.g. in Iran and Zimbabwe, which can have a fundamental impact on a society and can therefore lead to unforeseen leaps in societal evolutions.

\section{Implications for ICTs in Development}

The above outlined modernization theoretical way of thinking serves as an ideological basis for strategies of neo-liberal IT-development politics, purely focused on economic benefit resulting out of

In comparison, Austria is on the 21st place, but other European Union countries are ranked behind Saudi Arabia: Hungary (place 63), Lithuania (place 69), Poland (place 71), Latvia (place 72), Bulgaria (place 86), Romania (place 90). competition. The idea behind it is that economic development based on free, deregulated markets will automatically lead to societal progress and wealth for all. Developing countries should adopt the Western economic system, monitored by institutions such as the World Bank, which includes large privatisation activities. This approach actually does not support developing countries on their way to an inclusive information society, in contrary, it favours and strengthens Western economic and cultural hegemony. Braga et al. for example state in a position paper for the World Bank that "(...) the challenges are substantial. The possibility that the gap already existing between the front-runners of the networking revolution (mostly highincome economies) and those lagging behind (mostly low-income countries) may still grow larger, raises the spectre of a 'digital divide'. The concern here is not restricted to the issue of connectivity per se; it also includes the implications of connectivity (or lack of it) for economic growth and the broader agenda of sustainable development. The danger faced by all is that digital divide may reinforce patterns of divergence both internationally and within countries". The authors also stress the "digital opportunities", which go side by side with the challenges for developing countries, when they point out that developing countries "(...) can scientifically benefit from investments in modern information infrastructure in a procompetitive regulatory environment, and leapfrog stages of development in terms of networking roll-out" (Braga et al., 2000, p. 1$2)$. One can clearly see the modernization theoretical idea behind it: "leapfrog stages of development" refers to the assumption that development follows a one-dimensional, determent line, from divers traditional societies towards Western streamlined modern, capitalistic societies. A similar example of this sort can be seen in the International Telecommunication Union (ITU). In the first sentence of their vision statement for Least Developed Countries (LDCs) it is stated: "The Programme for the least developed countries (LDCs) and small island developing states (SIDS) and 
emergency telecommunications will be valued for its quality and timely service aimed at integrating LDCs and SIDS into the world economy through information and communication technologies (ICT) [...]" (ITU, 2009).

The latest catchword in this context is 'public-private partnership'. Nongovernmental organisations (NGOs) more and more create joint ventures with partners from the private sector. Various publicprivate partnership projects, for example UNESCO currently cooperates with Google and Microsoft, again illustrate modernization theoretical ideas. UNESCO, who launched an open-software project sponsored by Microsoft in 2004, legitimises such cooperations in the following way: "These partnerships serve to illustrate the close link between sustainable development and the creation of wealth through commercial activity." (UNESCO, 2009) Companies like Google and Microsoft have so far not been known that well for open- and free-software and therefore one might wonder about the underlying reasons. The developing world will become a huge IT market in the next years and the key players in the global technostructure would probably not relinquish it to initiatives such as Negroponte's One Laptop per Child project and therefore it might be possible that Western companies use such co-operations to prepare the market entry to sell their already existing products, which are based on patterns of use prevalent in (post)industrialised countries. Michel J. Menou (2008) concludes on public-private partnerships that "step by step public interest and common goods are sacrificed to the alleged efficiency of private sector ventures".

Since external and internal factors are hardly predictable, modernization theories furthermore neglect that it is uncertain how the technology will be used (for different examples see Bichler, 2007; 2008a; 2008b; 2008c). A good illustration for the internal configuration of technology use due to changing societal circumstances can be found in Kenya where a mobile banking transaction system became popular during the civil unrests in 2007. During that time, when traditional channels for the movement of money, e.g. sending money via friends and family on a bus, were cut off, this service became a tool for the maintenance of urbanrural relations (Morawczynski, 2008, p. 110) She concludes: "The M-PESA application is being widely adopted by low-income migrants for the transfer of remittances between urban and rural areas, and becoming a substitute for many of the other money transfer services." (Morawczynski, 2008, p. 122)

\section{Concluding Thoughts}

In this position paper we have tried to highlight the shortcomings associated with modernization theoretical thinking in ICTs based development assistance. In our opinion the main deficit of such approaches is the lack of any useful description why development should constitute this way. Modernization theories reflect the ethnocentric self-approval and the political and economical superiority of Western (post)industrialised countries. Such approaches are focusing solely on economic development based on free, deregulated markets. Following such an understanding, the Western world acts as a role model for developing countries through which hegemonic politics with the goal to introduce a neoliberal economic system on a global scale in favour of Western companies are justified. For further research we propose the following working hypotheses:

$>$ When development assistance continues to be taken out in modernization theoretical ways, the economic dependency of developing countries will increase.

$>$ The more Western companies get involved in ICTs based development assistance, the more it is unlikely that developing countries start building their own technological capacities.

$>$ When the dominance of Western online content, along with the propagation of the Western life style concerning different spheres of life, continues, the opposing forces against Western cultural hegemony in developing countries will rise. 


\section{References}

Abramowski, G. (1966). Das Geschichtsbild Max Webers. Universalgeschichte am Leitfaden des okzidentalen Rationalisierungsprozesses. Stuttgart: Ernst Klett Verlag.

Braga, C. A. \& Kenny, C. \& Qiang, C. \& Crisafulli, D. \& Martino, D. D. \& Eskinazi, R. \& Schware, R. \& Kerr-Smith, W. (2000). The networking revolution: Opportunities and challenges for developing countries (working paper). Washington DC: World Bank Group. Retrieved April 15th, 2007, from http://www.infodev.org/library/working.html.

Bichler, R. M. (2007). Information and Communication Technologies for Least Developed Countries (ICTs4LCDs): Exemplified in the Republic of Yemen. The International Journal of Interdisciplinary Social Sciences, 2(2), pp. 349360.

Bichler, R. M. (2008a). Information and Communication Technologies in the Republic of Malawi: An Assessment of Progress and Challenges Ahead. In A. O. Bada \& P. Musa (Eds.), Proceedings of the IFIP WG 9.4 Joint Workshop at University of Pretoria: Towards an ICT Research Agenda for African Development (pp. 189-202). Pretoria: International Federation for Information Processing.

Bichler, R. M. (2008b). Southern Africa and the Digital Divide: A Malawian Case Study. The International Journal of Technology, Knowledge and Society. 4(6), 41-50.

Bichler, R. M. (2008c). The dawn of the information age in least developed countries (LDCs): lessons learned from four case studies. TripleC, 6(2), 77-87.

Fuchs, C. (2008). Deconstructive Class Analysis: Theoretical Foundations and Empirical Examples for the Analysis of Richness and the Class Analysis of the Media and the Culture Industry. ICT\&S Research Paper No. 4, ICT\&S Center, Salzburg. ISSN 1990-8563. Retrieved November 25, 2009, from: http://icts.sbg.ac.at/media/pdf/pdf1666.

Harrison, D. (1988). The Sociology of Modernization and Development. London: Unwin Hyman Ltd.

International Telecommunication Union (ITU). (2009). Vision Statement. Retrieved November 25, 2009, from: http://www.itu.int//TU-D/ldc/vision.html.

Lachmann, W. (2004). Entwicklungspolitik. Band 1: Grundlagen. München: Oldenbourg Verlag.

Menou, M. J. (2008). ImperiallCTism the Highest Stage of Capitalism? Keynote address, INFO 2008, La Habana, Cuba 2125 de Abril de 2008, Foro Sociedad del conocimiento: nuevos espacios para su construccion.

Menzel, U. (1995). Geschichte der Entwicklungstheorie. Einführung und systematische Bibliographie. Hamburg: Deutsches Übersee-Institut.

Morawczynski, O. (2008). Surviving in the 'dual system': How M-PESA is fostering urban-to-rural remittances in a Kenyan Slum. In A. O. Bada \& P. Musa (Eds.), Proceedings of the IFIP WG 9.4 Joint Workshop at University of Pretoria: Towards an ICT Research Agenda for African Development (pp. 110-127). Pretoria: International Federation for Information Processing.

Nuscheler, F. (2005). Entwicklungspolitik. Lern und Arbeitsbuch. Ulm: Ebner \& Spiegel GmbH.

Rostow, W. W. (1960). Stadien wirtschaftlichen Wachstums. Eine Alternative zur marxistischen Entwicklungstheorie. Göttingen: Vandenhoeck \& Ruprecht.

United Nations Educational, Scientific and Cultural Organization (UNESCO) (2009). Private Sector Partnerships. Retrieved November 25, 2009 from: http://portal.unesco.org/ci/en/ev.phpURL_ID=17587\&URL_DO=DO_TOPIC\&URL_SECTION=201.html.

United States Central Intelligence Agency (2009): The World Factbook 2009. Retrieved November 25, 2009 from: https://www.cia.gov/library/publications/the-world-factbook/rankorder/2004rank.html

Wallerstein, I. (2004). World-System Analysis. An Introduction. London: Duke University Press.

Wehler, H-U. (1975). Modernisierungstheorie und Geschichte. Göttingen: Vandenhoeck \& Ruprecht.

Werlen, B. (2008). Sozialgeografie. Eine Einführung. Stuttgart: UTB.

\section{About the Authors}

Robert M. Bichler

Robert M. Bichler is lecturer at the Shanghai International Studies University (SISU) and member of the Unified Theory of Information (UTI) Research Group - Association for the Advancement of Information Sciences. Prior he was a research fellow and lecturer at the ICT\&S Center at the University of Salzburg. Address: Shanghai International Studies University, German Department, 550 Da Lian Road (W), Shanghai 200083, P.R. China. [email: robert.bichler@uti.at] 
Eva Gaderer

Eva Gaderer completed her Bachelor degree in Communication Studies, majoring in media economics and international communication at the University of Salzburg. Currently she is doing her masters degree and writing her thesis about strategies and actors in development politics in Nicaragua with a special consideration of the role of (new) media. From 2007 until Dec. 2009 she was working as public relations-assistant and assistant coordinator of the MCM - Program (Master Exchange Program in Media and Communication Management) as a member of the ICT\&S Center at the University of Salzburg support staff. [email: eva.gaderer@sbg.ac.at] 